\title{
Multiple Calcifying Epitheliomas of Malherbe's of Axilla: A Case Report of Rare Variety
}

\author{
Mushtaq Chalkoo*, Shahnawaz Ahangar, Naseer Awan, Mujahid Ahmad Mir, Aarif Bashir, \\ Nida Shafiq
}

Department of General Surgery, Government Medical College, Srinagar, India

Email: ${ }^{*}$ mushtaq chalkoo@rediffmail.com

Received 25 April 2014; revised 20 May 2014; accepted 27 May 2014

Copyright (C) 2014 by authors and Scientific Research Publishing Inc.

This work is licensed under the Creative Commons Attribution International License (CC BY).

http://creativecommons.org/licenses/by/4.0/

c) (i) Open Access

\begin{abstract}
Pilomatrixoma, a rare benign tumour of sebaceous gland is commonly known as calcifying epithelioma of Malherbe or Tricholemmal cyst. We came across even the rarest form of this benign tumour of skin. Our case report was interestingly detected at a higher age group, unusual site of the body, multiple in nature following postoperative incision drainage of abscess in left axilla.
\end{abstract}

\section{Keywords}

Epithelioma, Axilla, Multiple, Postsurgical

\section{Introduction}

Epithelioma of Malherbe is a rare benign tumour of skin arising from its appendage, sebaceous gland. They are usually found in children and young adults with predominance in Caucasian race. The tumour originates from hair follicle and is usually seen in first two decades of life. These rare tumours usually are solitary and present as firm, painless, slow growing nodules with discoloration of overlying skin. The diameter of tumour ranges from 0.5 to $3 \mathrm{~cm}$ in most cases. The Epithelioma in our case report was detected from an unusual site of body i.e., left axilla, and it was multiple, in a higher age group and occurring after 20 years of post surgical drainage of axillary abscess, which makes it interestingly even rarer to the tune of 3.5\%. Clinical differential diagnosis includes epidermoid cysts, dermoid cyst, sebaceous adenoma or carcinoma, juvenile xanthogranuloma, capillary hemangioma, chalazion, and rhabdomyosarcoma. Although they grow slowly, they occasionally demonstrate rapid growth and may resemble keratoacanthoma. They can rarely undergo malignant transformation into pilomatrix

*Corresponding author.

How to cite this paper: Chalkoo, M., Ahangar, S., Awan, N., Mir, M.A., Bashir, A. and Shafiq, N. (2014) Multiple Calcifying Epitheliomas of Malherbe's of Axilla: A Case Report of Rare Variety. Surgical Science, 5, 242-245. 
carcinoma. Management includes a complete excision biopsy if there is any clinical suspicion of pilomatrixoma based on the clinical feature.

\section{Case Report}

A forty years old male patient was presented in our out-patient department with a painful swelling left axilla from last 3 months. The swelling gradually increased in size and was not associated with any constitutional symptoms like fever, rigors chills, weight loss, chronic cough, breathlessness, or any other swelling anywhere in the body. The patient was operated upon for incision drainage of abscess in this area some 20 years ago. General physical examination and systemic examination were normal. Local examination showed $2 \mathrm{~cm}$ scar in left axilla medially. A $3 \times 3 \mathrm{~cm}$ swelling was noted in left axilla, on medial wall, mobile, non tender, skin overlying the swelling free (Figure 1). Routine baseline investigations were within normal limits. FNAC (fine needle aspiration cytology) of swelling revealed Calcifying Epithelioma of Malherbe. The patient was operated by making an elliptical incision over the swelling making sure to excise the previous scar along with the lesion (Figure 2). The specimen was sent for histopathlogical examination which revealed Calcifying Epithelioma of Malherbe (Figure 3(a), Figure 3(b)).

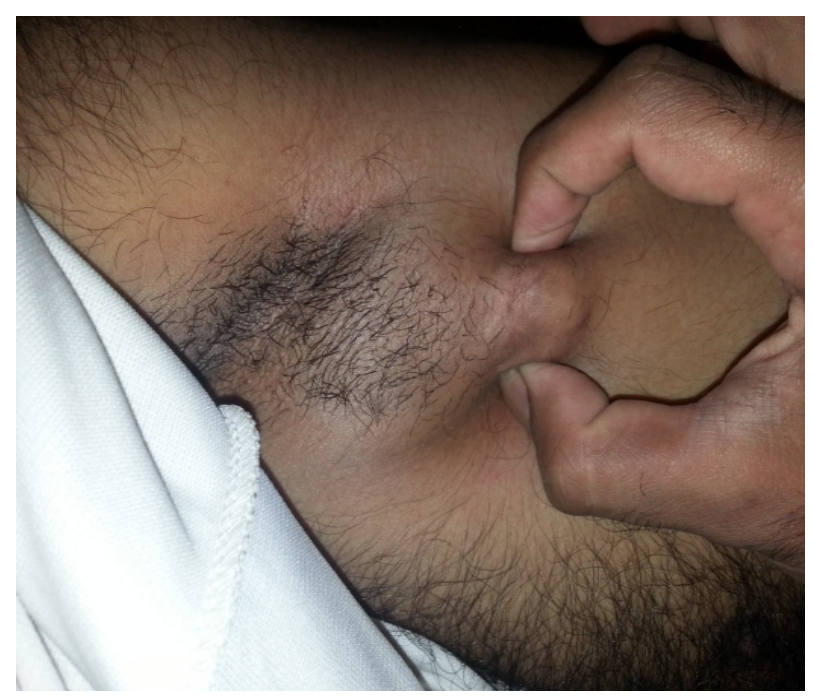

Figure 1. The clinical presentation of the swelling.

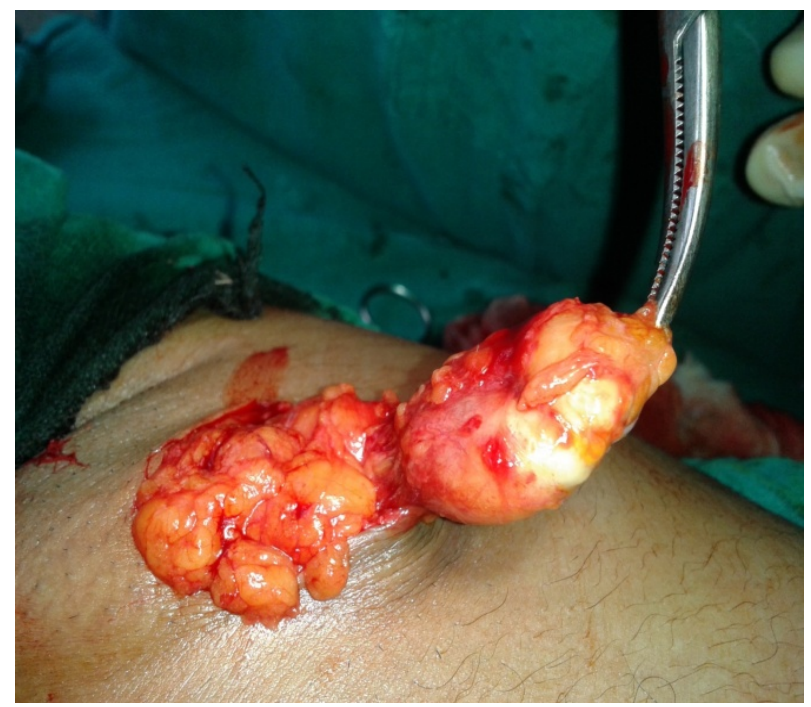

Figure 2. Showing the excision biopsy of the swelling. 


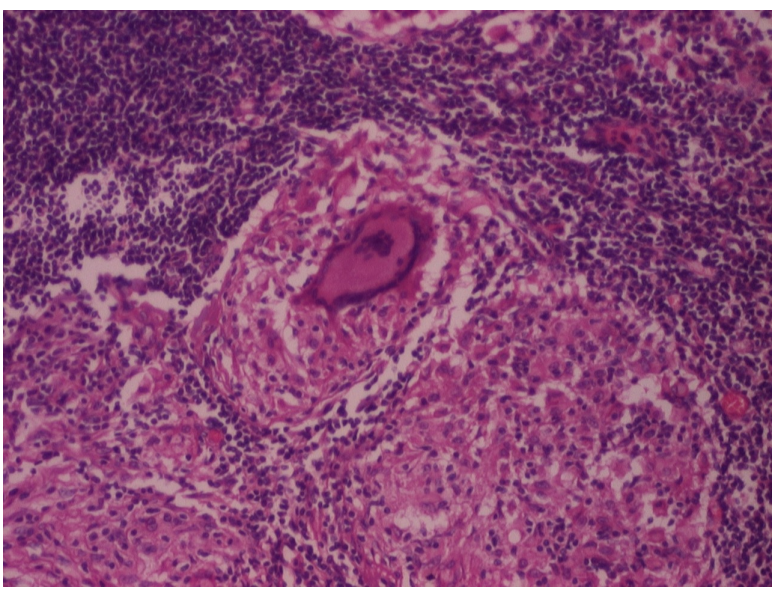

(a)

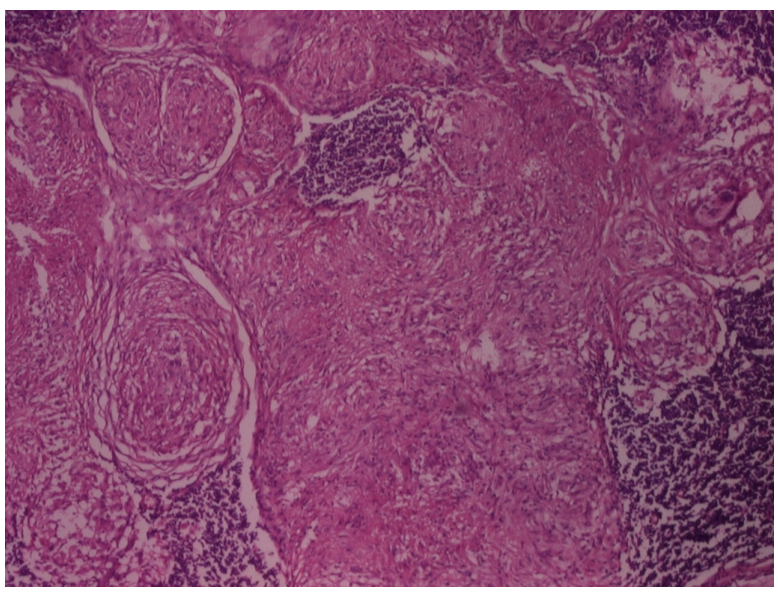

(b)

Figure 3. (a) Pictomicrograph of the swelling; (b) Pictomicrograph of the swelling.

\section{Discussion}

The Calcifying Epithelioma of Malherbe is remembered in the honor of Malherbe and Chenantais who described it in the year 1880 and thought it to arise from sebaceous gland [1]-[3]. The benign lesion is also known as Pilomatrixoma and is reported with a female male ratio of 3:4 predominantly seen in Caucasian race [4] [5]. The lesion primarily affects children and adolescents, with $40 \%$ of cases occurring before age $10 \%$ and $60 \%$ before age 20 [6]-[8]. The greatest incidence of this tumor is found in patients between 8 and 13 years of age however, our case is reported in forty years of age following incision drainage of an abscess making it interestingly different. The tumour is rare and is frequently misdiagnosed as dermoid or epidermoid. It is usually solitary but multiple foci have been reported in 3.5\% of all cases. They most commonly involved sites are head and neck region followed by upper extremities, trunk, and lower extremities [9]. Our case was detected from axilla, a rarer site and was multiple in nature. Multiple pilomatrixomas and multiple familial pilomatrixomas have been associated with myotonic dystrophy, Gardner syndrome, and Rubinstein-Taybisyndrome. Diagnosis of pilomatrixoma can often be made solely on the basis of clinical features. Differential diagnosisof head and neck pilomatrixoma includes dermoid cysts, branchial cleft remnants, preauricular sinuses, adenopathy, sebaceous cysts, giant cell tumor, chondroma, foreign body reaction or malignant soft tissue tumors [10]-[14]. Fine-needle aspiration has been described as a preoperative diagnostic method. Malignant transformation of pilomatrixoma is rare. Rare cases of pilomatrix carcinoma with distant metastasis have been reported. Since spontaneous regression is never observed, the standard treatment of pilomatrixoma is complete surgical excision.

\section{Conclusion}

Pilomatrixoma is a rare skin tumour in children and young adults and multiple pilomatrixomas in elderly are very rare. Our case of multiple pilomatrixomas in a male patient previously operated for axillary abscess, noted in a higher age group is even rarer.

\section{References}

[1] Malherbe, A. and Chenantais, J. (1880) Note sur l' epitheliomaca lcifie des glandes sebacees. Bulletins de la Société anatomique de Paris, 15, 169-176.

[2] Ali, M.J. and Honavar, S.G. (2011) Malherbe’s Calcifying Epithelioma (Pilomatrixoma): An Uncommon Periocular Tumor. International Journal of Trichology, 3, 31-33.

[3] Forbis Jr., R. and Helwig, E.B. (1961) Pilomatrixoma (Calcifying Epithelioma). Archives of Dermatology, 83, 606-618. http://dx.doi.org/10.1001/archderm.1961.01580100070009

[4] Moehlenbeck, F.W. (1973) Pilomatricoma (Calcifying Epithelioma): A Statistical Study. Archives of Dermatology, 108, 532-534. http://dx.doi.org/10.1001/archderm.1973.01620250020004

[5] Knight, P.J. and Reiner, C.B. (1983) Superficial Lumps in Children: What, When, and Why? Pediatrics, 72, $147-153$. 
[6] Hills, R.J. and Ive, F.A. (1992) Familial Multiple Pilomatrixomas. British Journal of Dermatology, 127, 194-195. http://dx.doi.org/10.1111/j.1365-2133.1992.tb08062.x

[7] Yencha, M.W. (2001) Head and Neck Pilomatricoma in the Pediatric Age Group: A Retrospective Study and Literature Review. International Journal of Pediatric Otorhinolaryngology, 57, 123-128. http://dx.doi.org/10.1016/S0165-5876(00)00449-3

[8] Yap, E.Y., Hohberger, G.G. and Bartley, G.B. (1999) Pilomatrixoma of the Eyelids and Eyebrows in Children and Adolescents. Ophthalmic Plastic \& Reconstructive Surgery, 15, 185-189. http://dx.doi.org/10.1097/00002341-199905000-00008

[9] Kang, H.Y. and Kang, W.H. (2000) Guess What Perforating Pilomatricoma Resembling Keratoacanthoma. European Journal of Dermatology, 10, 63-64.

[10] Mencia-Gutierrez, E., Gutierrez-Diaz, E., Garcia-Suarez, E. and Ricoy, J.R. (2002) Eyelid Pilomatricomas in Young Adults: A Report of 8 Cases. Cutis, 69, 23-26.

[11] Yencha, M.W. (2001) Head and Neck Pilomatricoma in the Pediatric Age Group: A Retrospective Study and Literature Review. International Journal of Pediatric Otorhinolaryngology, 57, 123-128. http://dx.doi.org/10.1016/S0165-5876(00)00449-3

[12] Martelli, G. and Giardini, R. (1994) Pilomatrix Carcinoma: A Case Report and Review of the Literature. European Journal of Surgical Oncology, 20, 703-704.

[13] Singh, K., Sharma, S., et al. (2002) Calcifying Epithelioma of Malherbe. JK Science, 4, 101-102.

[14] Chuang, C.-C. and Lin, H.-C. (2004) Pilomatrixoma of the Head and Neck. Journal of the Chinese Medical Association, 67, 633-636. 